UDC 930:94(477)"16"

DOI 10.24919/2519-058X.20.240044

\begin{abstract}
YURij STEPANCHUK
PhD hab. (History), Associate Professor, Professor of the Department of History and Culture of Ukraine of Vinnytsia State Pedagogical University named after M. Kotsiubynskyi, 32 Kostiantyn Ostrozkyi'Street, Vinnytsia,Ukraine,postal code 21001 (iiepp@ukr.net)
\end{abstract}

ORCID: 0000-0001-6693-1463

\title{
Oksana FEDURKO
}

PhD (Philology), Associate Professor of the Department of Philological Disciplines and Methods of Their Teaching in the Primary School of Drohobych Ivan Franko State Pedagogical University,vul.I. Franka, 24, Drohobych,Ukraine, postal code82100 (mfedurko@ukr.net)

ORCID: 0000-0002-2842-0555

\section{Юрій СТЕПАНЧУК}

доктор історичних наук, дочент, професор кафедри історї та культури України Вінницького державного педагогічного університету імені Михайла Кочюбинського, вул. Костянтина Острозького, 32, м. Вінниця, Україна, індекс 21001 (iiepp@ukr.net)

\section{Оксана ФЕДУРКО}

кандидат філологічних наук, дочент кафедри філологічних дисииплін та методики їх викладання у початковій школі Дрогобицького державного педагогічного університету імені Івана Франка, вул. I. Франка, 24, м. Дрогобич, індекс 82100 (mfedurko@ukr.net)

Bibliographic Description of the Article: Stepanchuk, Yu. \& Fedurko, O. (2021). The Concept "Ruin": Modern Historiographical Discourse. Skhidnoievropeiskyi Istorychnyi Visnyk [East European Historical Bulletin], 20, 216-226. doi: 10.24919/2519-058X.20.240044

\section{THE CONCEPT “RUIN": MODERN HISTORIOGRAPHICAL DISCOURSE}

\begin{abstract}
The purpose of the research is to study the modern historiographical discourse related to the scientific circulation of the concept "Ruin" in the context of conceptualizing the history of the Hetmanate. The research methodology is based on the methods'symbiosis usage: comparative studies, contextual analysis, convergence from the abstract to the concrete and vice versa. The scientific novelty of the article is that for the first time the specifics of the approaches implemented by modern researchers to the use of the concept of "Ruin" for the interpretation of early modern Ukrainian history have been analyzed in historiography. The essence of the discussion concerning the concept marking feasibility of a special period in the second half of the XVIIth century has been investigated and its echo in further conceptualizations. The Conclusions. Taking into consideration that the modern scientific discourse on the concept "Ruin" reflects the key tendencies in understanding the history of early modern Ukrainian statehood. The issue reached the point of discussion concerning the grounds for using the concept at the beginning of the XXIst century for the first time in historiography, while in the previous tradition it was used without being discussed. Consequently, the discussion was translated into the plane of elucidating the image of the epoch, which forms the concept not only in scientific interpretive models, but also in the historical memory of the public. The comparative approach and typology of the Ukrainian version against the European background were used, which provided the brand new opportunities for improving
\end{abstract}


the terminological apparatus related to the era conceptualization and marking. Furthermore, the substantive discussion between T. Chukhlib, the Ukrainian historian and T. Tairova-Yakovleva, the Russian researcher became the controversy. As a result, the above-mentioned discussion triggered a smooth refusal of the concept "Ruin" usage in historiography, especially noticeable in Ukraine.

Key words: Ukraine, Ruin, interpretation, conceptual apparatus, scientific discourse.

\title{
ПОНЯТТЯ “РУЇНА”: СУЧАСНИЙ ІСТОРІОГРАФІЧНИЙ ДИСКУРС
}

\begin{abstract}
Анотація. Мета дослідження полягає у дослідженні сучасного історіографічного дискурсу, пов'язаного з науковим обігом поняття "Руїна", у контексті конщептуалізаиії історії Гетьманщини. Методологія дослідження передбачає використання симбіозу методів компаративістики, контекстуального аналізу, сходження від абстрактного до конкретного і навпаки. Наукова новизна статті полягає в тому, що вперше в історіографії проаналізовано специфіку підходів сучасних дослідників до використання поняття "Руїна" для інтерпретаиії ранньомодерної украӥнської історії. Досліджено сутність дискусії про доиільність маркування ииим поняттям особливого періоду в рамках другої половини XVII ст. та ії відгомін у подальших концептуалізаціях. Висновки. Сучасний науковий дискурс навколо поняття "Руїна" відбиває ключові тендениії в осмисленні історії ранньомодерної украӥнської державності. На початку XXI cm. уперше в історіографії проблема вийшла на рівень обговорення підстав використання поняття, тоді як у попередній традиції воно вжсивалося не продискутованим. Обговорення було переведено до площини з'ясування того образу епохи, який формує поняття не тільки в наукових інтерпретаиійних моделях, ай уісторичній пам'яті широкого загалу. Залучено компаративістичний підхід та типологізачію українського варіанта на європейському тлі, що створило нові можсливості для удосконалення термінологічного апарату, пов'язаного з концептуалізацією та маркуванням доби. Фокусом полеміки стала предметна дискусія між украӥнським істориком Т. Чухлібом та російською дослідницею Т. Тайровою-Яковлевою. Ця дискусія стимулювала плавний відхід в історіографії від використання поняття "Руїна", особливо помітний в Украӥні.
\end{abstract}

Ключові слова: Украӥна, Руїна, інтерпретаиія, понятійний апарат, науковий дискурс.

The Problem Statement. Researches intensification on different issues related to the history of early modern Ukrainian statehood, caused intensification of optimal terminological support issues of the research process. Consequently, the conceptual apparatus becomes the subject of professional discussion in order to filter the optimal model of usage, which would reflect scientific ideas adequately and unjustified modernization of concepts. Second of all, the very process is quite natural, taking into account the purely research objectives and the close connection of historical terminology with the past images formation in the public historical memory. Along with the discussions concerning the central concept for the typology of the epoch, which is considered to be Bohdan Khmelnytskyi era marker, in some period of time, it came to a substantive discussion on the application legitimacy of the category "Ruin" to the processes of the second half of the XVIIth century. As a result, the scientific circulation issue and the context of usage / non-usage of this term brought in the process analysis and the formation consequences in the modern intellectual tradition of the Hetmanate image tonality. Accordingly, elucidating the evolution of scientific approaches to the usage of the concept "Ruin", known in historiography since the second half of the XIXth century, is important in terms of singling out not only the specifics of its usage in early modern times, but also the features of modern concepts of early modern Ukrainian history.

The Analysis of Recent Researches. It should be mentioned that the concept "Ruin" was not yet the subject of special analysis in the modern scientific discourse. The historiography of the issue is represented only by some significant observations. The main participants of the above-mentioned substantive discussion were T. Chukhlib and T. Tairova-Yakovleva, hence, 
the majority of the observations on the prospects of the term usage to denote the relevant period, belong to them. Both researchers limited themselves to stating the supporters of the concept "Ruin" and succinct remarks concerning the motives of some of them (Chukhlib, 2004, pp. 488-508; Yakovleva, 2005, pp. 667-672), without having any intentions to do an in-depth analysis of the historiographical situation. The only attempt, which was made, to present the actual historiographical section belonged to V. Maslak, who mentioned the place of the concept in the terminological apparatus of modern Russian and Polish researchers briefly, and also drew attention to the discussion between T. Tairova-Yakovleva and T. Chukhlib (Maslak, 2014, pp. 69, 209-210). As a result, the above-mentioned observations became fruitful intellectual nourishment for further research.

The purpose of the research is to study the modern historiographical discourse related to the scientific circulation of the concept "Ruin" in the context of conceptualizing the history of the Hetmanate.

The Main Material Statement. Owing to M. Kostomarov, the concept "Ruin" spread in the historiographical space quickly and painlessly. Furthermore, the concept "Ruin" began to be used not only in the Ukrainian historiography but also in Russian and Polish partly. The concept marked the main period for the fate of early modern Ukrainian statehood, which occurred right after Bohdan Khmelnytskyi's death and, eventually, the Hetmanate ended with the narrowing to the Left Bank and the Hetmanate's sovereignty decline in favour of Moscovia (the Grand Dutchy of Moscow). The victorious march of the concept "Ruin" was interrupted only at the territory of the USSR in the 1940s and 1980s on purely ideological reasons, because after "the triumph of historical justice" (that is how the official Soviet canon interpreted the Pereyaslav Council (Pereyaslavska Rada) of 1654) nothing like the "Ruin" could have happened in Ukraine (Chukhlib, 2004, p. 489). Otherwise, the whole construction of the Sovietized great-power explanation of further Ukrainian history, sustained within the framework of the concept of the "greatest good", would be undermined. Instead, in the Ukrainian diasporic historiography, the concept continued to be present in the intellectual circulation (Kohut, 1996, p. 36; Ohloblyn, 2001, p. 65; Subtelny, 1989, p. 139).

In addition, a similar situation was observed in the Polish historiography of the second half of the XXth century, which was considered to be one of the most powerful scientific forces in the field of research and early modern Ukrainian history interpretation (Serczyk, 1979, p. 168; Perdenia, 2000, p. 11; Wójcik, 1989, p. 6, 79). Z. Wójcik's thesis summarized the Polish historians' approaches decently that in the 1660s Ukraine "entered the period of "Ruin" - one of the most tragic in its history" (Wójcik, 1989, p. 8). At the same time, the researcher completely agrees with the historiographical tradition of using the concept "Ruin" in relation to that time, using the following phrase "the period of history, known in historiography as "Ruin" (Wójcik, 1989 , p. 79). One more researcher, Z. Kohut shared the same point of view and even wrote in a similar style on the pages of his monograph, which was first published in 1988: "This period is known in the Ukrainian historiography as "Ruin" (Kohut, 1996, p. 36). Taking everything into account, the above-mentioned information symbolized the conceptual consensus between contemporary Polish and foreign Ukrainian historiography.

It is quite paradoxically, however, that despite the spread of "Ruin" in the historiographical space, the expediency of using such a concept-marker until recently was not discussed in historiography properly. Moreover, the attempts made by O. Ohloblyn, dated back to 1928 to the interpretation issue of this period in the categories of "Ruin" were not conceptualized even by the author himself (Ohloblyn, 1928, p. 200) and remained without any professional 
discussion in the Ukrainian historiography. Thus, the effect of the so-called historiographical "chatter" was created, when as a result of long-term usage a certain statement or concept is recepted stereotypically as appropriate, almost as an axiom, and is no longer scientifically tested. It was facilitated greatly by the fact that the concept "Ruin" wedge well in the dominant interpretations of the Ukrainian and Polish historiography, immersed in its roots in the texts, written in the XVIIth - XVIIIth centuries. For the Ukrainian historiography, the Civil War along with the external forces active intervention, which was literally cutting the wings of the restored statehood in the middle of the XVIIth century, acquired gloomy feature simplicitly. For the Polish historiography, these phenomena worked well for the concept of the total harmfulness of the attempt on the integrity of Rzeczpospolita (the Polish-Lithuanian Commonwealth) and the Ukrainian society position in it.

After the USSR collapse and the fall of the "Iron Curtain", the concept "Ruin" regained its position in Ukraine quickly, which was accompanied by active development of the heritage of foreign Ukrainian historians and a closer acquaintance with the latest developments implemented by the Polish researchers. In 1990, owing to Yu. Mytsyk, the concept "Ruin", appeared on the pages of the Ukrainian Historical Journal, which, even taking into account the significantly relaxed ideological control of the late USSR, meant a kind of legitimization of the concept. Moreover, the concept was heralded in a conceptual discussion within the framework of the round table "The Ukrainian Cossacks: the current state and prospects of research", which was organized by the same magazine (Mytsyk, 1990, p. 25). In addition, V. Smolii and V. Stepankov, invited the scientific community to discuss the early modern Ukrainian statehood issue, which used the concept "Ruin" actively two years later (Smolii, Stepankov, 1993, pp. 26, 47).

Later on, the concept "Ruin" entered both scientific discourse and historical journalism smoothly. As a result, the concept "Ruin" was presented across the spectrum: from general publications on the Ukrainian history up to the specialized articles, from popular literature - to school textbooks and programmes. In general textbooks, which were called "The Histories of Ukraine", the concept may be even found in the titles of sections (Mytsyk, Bazhan, Vlasov, 2010 p. 126; Yakovenko, 2005, p. 370), which reflected its entry into the orbit of key categories for the interpretation of the early modern era. At the same time, the concept usage remained unreflected for a long time. Moreover, the concept "Ruin" was taken for granted. This is because, the role of a kind of indulgence was played by its expressive historicity, because the term "Ruin" was really in the Hetmanate in intellectual circulation at the second half of the XVIIth mid XVIIIth centuries. In addition, there were even calls to avoid the excessive modernization of concepts and to describe the past as much as possible in the categories inherent in the studied time intensified the tendency (Kasianov, Tolochko, 2012, p. 20).

In 1994, the dissertation, written by St. Petersburg researcher Tetiana Tairova-Yakovleva, did not change the general mood, and in 1998 the monographs were devoted to the conceptualization of the era as "Ruin" (Yakovleva, 1998). "Ruin, in particular, the historical period that lasted from the time of Bohdan Khmelnytskyi's death until the end of the XVIIth century, occupies a special place in the history of Ukraine", the researcher began her book with this thesis, describing the concept as a common roof for all events of that time and processes that took place in the Hetmanate (Yakovleva, 1998, p. 5). It should be highlighted that the reviews published in Ukraine for this book, despite a number of critical arrows, did not mention the legitimacy issue concerning the use of the concept as an image of the day. It was only about the vagueness of the chronological framework of the "Ruin". 
However, the general revision of the conceptual apparatus of early modern Ukrainian history, typical of the end of the XXth and at the beginning of the XXIst centuries, could not sooner or later affect the "Ruin". Moreover, the terminology related to the problem of marking the social explosion in Ukraine in the middle of the XVIIth century was extremely actively discussed and is still being discussed. And the above-mentioned discussion continues to this day, periodically erupting in the Ukrainian historiography with renewed vigor.

Furthermore, the impetus for reflections on the concept "Ruin" was the appearance of the second monograph by T. Tairova-Yakovleva "The Ruin of the Hetmanate..." in 2003 (Yakovleva, 2003). The book triggered a discussion about approaches to the usage of the term. At first, the participants of the terminological discussion, which took place within the framework of the international conference "Ukraine and Neighboring States in the XVIIth Century", mentioned the issue. T. Tairova-Yakovleva raised the issue, noting that the Ukrainian researchers T. Chukhlib and V. Horobets were "categorically against" the usage of the term "Ruin". The researcher put emphasis on that "to talk about whether or not there was Ruin, in particular, the problems of internal and external development of the Hetmanate at the end of the $50 \mathrm{~s}$, the $60 \mathrm{~s}$ and the 70 s of the XVIIth century". - This is a matter of principle". At the same time T. Tairova-Yakovleva raised the issue sharply, proposing a dilemma on the principle of "either - or": "If we abandon to usage of the term "Ruin", then we say that everything was fine there, everything was good" (Yakovleva, 2004, p. 231). However, despite all the ambiguity of such a resolution of the issue and open controversy, the problem was not widely discussed. Yu. Mytsyk supported the researcher with one phrase (Yakovleva, 2004, p. 231). Moreover, the rest of the participants limited themselves to silence, focusing on a comprehensive discussion of terminology, which was related to the era of B. Khmelnytskyi.

As a result, T. Chukhlib presented his position on the "Ruin" right after the conference, as if confirming what T. Tairova-Yakovleva said about his negative attitude to the usage of the concept as a marker for the whole period of early modern Ukrainian history. It was this researcher, who was destined to become the driver of the transfer in the modern scientific literature of the position on "Ruin" and to the analysis of the meanings it imposes on the intellectual image of the day and on the corresponding slice of historical memory of the general public. In fact, T. Chukhlib did not hide that he intended to initiate a scientific discussion on the validity of strategies for continuing the ancient terminological tradition. Moreover, his substantive article contains a specific subtitle: "The Attempt to Initiate a Scientific Discussion of Historical Term" (Chukhlib, 2004, p. 473). However, behind the above-mentioned modest statement there was actually a deep understanding of the problem against the broad background of the processes that began in Ukraine under the sign of the war, which led to the restoration of the Ukrainian statehood in the form of the Hetmanate.

In addition, the researcher pointed out directly that he considered his version as a continuation of the discussion about the nature of B. Khmelnytskyi era, started by V. Stepankov in the famous article "1648: The Ukrainian Revolution Outburst "wojna domowa (civil war)" in the Commonwealth" (Stepankov, 2003, p. 369). T. Chukhlib proposed to expand the format of assessing the feasibility of using the concept "Ruin" by combining two options: the semantic content of the concept as such outside the historical context and the scientific qualification of the essence of historical realities to denote the concept. Consequently, the problem of using the term was raised to the point of crossanalysis through the prism of both purely scientific tasks and the politics of memory.

It should be highlighted that the very appeal to the semantics of the term "Ruin" inevitably creates a mixed feeling about its use, because in the Ukrainian language it means "complete 
collapse, destruction", "complete ruin, decline of something" and so on. And the assessment of how exactly the semantic content of the term correlates with the realities of the period to which it is proposed to apply, is the starting point of research tools of T. Chukhlib and determines the tone of judgments and conceptual generalizations. At the same time, the historian tries to filter the content that T. Tairova-Yakovleva invested in the concept "Ruin" in both monographs.

In addition, T. Chukhlib, while analyzing the peculiarities of the concept "Ruin" mentioning in the works of St. Petersburg researcher, noticed the evolution of her interpretation of the term (Chukhlib, 2004, p. 490). Initially, the term "Ruin" was used as a concept that characterizes socio-political phenomena and manifested itself in "the intensification of the struggle for power, the accumulation of internal problems and social tensions, civil war, kaleidoscopic change of Hetmans, foreign interference in internal affairs" as characteristic features of the period (Yakovleva, 1998, p. 5). However, a bit later T. Tairova-Yakovleva brought in a significant clarification: "Now "Ruin" is primarily a period of political crisis of the Hetmanate, which led to its final weakening and transformation into the political autonomy" (Yakovleva, 2003, p. 4). Hence, all other manifestations were the subject to this main identifier.

In general, T. Chukhlib's observations were decent and relevant and reflected the essence of T. Tairova-Yakovleva's approaches. One can only criticize the qualification of changes in the researcher's position as "a certain evolution". It seems that we should talk about a significant reformatting of the approach. After all, in the first interpretation brought in by T. TairovaYakovleva (in this context we will put in parentheses the material that serves the basis and the intermediate conclusions of the book) the "Ruin" forms only the idea of the accumulation of negative internal problems of a social and political nature. In the second case, a different interpretive model is formed. The delineation of the period as "Ruin" should suggest, first of all, the weakening process of the newly restored Ukrainian state and the narrowing of its selfsufficiency. And already as a refrain there are phenomena, the intertwining of which led to such a negative result from the point of view of the Ukrainian perspective.

It should be mentioned that the researcher's latest version was not a novelty. Rather, on the contrary, the change in the angle of view reflects her reception of the works of the Ukrainian historiography. In 1997 the concept "Ruin" was described as "the historiographical name of the tragic decline of the Ukrainian Cossack state in the second half of the XVIIth century and the terrible devastation of the Right Bank (Pravoberezhna) of Ukraine" in the "Small Dictionary of the History of Ukraine" (Small Dictionary, 1997, p. 345). It is noteworthy that when the researcher published the text in 1998, she did not adopt such an approach, and already while working on the second book, she recognized it as rational. Furthermore, T. Chukhlib also left behind the fact that in 1998 the raid of the so-called "ruin" used by T. Tairova-Yakovleva was probably due to negligence, but somehow extended to the period of B. Khmelnytskyi's Hetmanship. The above-mentioned infer could be traced in the researcher's thesis: "In this book, the Ruin will be considered as a period that began in Ukraine as a result of a social devastation (Khmelnytchyna, foreign invasions, a long-term war)" (Yakovleva, 1998, p. 6). Hence, it already potentially leads to shifting the emphasis in the interpretation of the very era of B. Khmelnytskyi, although in the future such a careless statement did not turn into a historiographical trend. Moreover, in the future T. Tairova-Yakovleva not only did not assume such ambiguities but a special explanation of the connection between the processes of the mid-1650s and political and social cataclysms of later times were made in the same book, where the above-mentioned quote was submitted (Yakovleva, 1998, pp. 97-98). 
The idea of genetic continuity between the B. Khmelnytskyi's era and the subsequent period of the Ukrainian history was the researcher's concept nucleus (and this was important in the context of the Russian historiography development) (Maslak, 2014, p. 233). As a result, T. Tairova-Yakovleva stuck to the above-mentioned idea in principle and invariably. The imperishable ditch that, in favor of the Russian-centric interpretation of the latter, the Russian historians dug between the political concepts implemented by B. Khmelnytskyi and I. Vyhovskyi consistently, between the reaction of the society to these concepts in both cases, was filled up. Although in other respects such longevity was recognized. The researcher removed the touch of exclusivity from I. Vyhovskyi's strategies and social cataclysms that shook the Hetmanate in 1658 - 1659 and later. Accordingly, T. Tairova-Yakovleva spotted elements of filling the social content of the concept "Ruin" in anti-Hetman speeches, which flared periodically up in 1651 - 1657, but were suppressed by B. Khmelnytskyi with an iron fist. Those speeches reflected the formation of deep internal contradictions, which in I. Vyhovskyi's time only broke the dam: "The elitist republican form of the Hetmanate's government and the military democratic nature of all its institutions gave rise to a deep internal conflict contradict each other... This situation caused an explosion of political ambitions among the Ukrainian officers and contributed to the flourishing of diplomatic intrigues around Ukraine... It is these internal problems and contradictions of the Cossack state that became the main prerequisite for the Ruin" (Yakovleva, 1998, pp. 97-98).

Moreover, T. Chukhlib opposed the usage of the concept "Ruin" in scientific circulation. He justified his position by claiming that "this historical term does not fully cover the complex processes of political, economic, social, as well as the cultural and spiritual life of the Ukrainians in the second half of the XVIIth century" (Chukhlib, 2004, p. 489). In addition, the researcher noted the negative impact of the concept on the formation of the image of the day in the historical memory of the general public not only in Ukraine. In his opinion, the concept sketches distorted ideas, because in this plane the game includes its multi-functionality inevitably: the everyday meaning of the term in the minds of the masses will impose a specific semantic touch (Chukhlib, 2004, p. 491).

T. Chukhlib's arguments revolved around the inconsistency of the semantic mainstream concept - "complete collapse, destruction" - with the realities of the Hetmanate of the second half of the XVIIth century. The researcher tried to substantiate his position in all directions and denied the legitimacy of the assessment in the category of "Ruin" of the political crisis of the Hetmanate, economy, social relations. There were also questions about the chronological framework. And the key tool was to fit the situation in the Hetmanate into the European context, as well as a comparative perspective with neighboring periods of the Ukrainian history, to which, of course, the concept "Ruin" was no longer applied.

The researcher demonstrated the full potential of comparative studies on the example of considering the political strategies of the Ukrainian Hetmans and the elite in general in relation to neighboring rulers against the background of the European counterparts. After all, the political ambitions and involvement of the contenders of the mace in the Ukrainian affairs of neighboring countries were one of the main catalysts for the internal struggle. The typological echo of the search for more favorable citizenship by different rulers in difficult internal and external circumstances, different effectiveness of subordination, in particular, sometimes sharply negative for the self-sufficiency and internal order of states, was demonstrated. As a result, it gave rise to the remark that by the logic of things and in such cases it is necessary to apply the concept "Ruin", which no one does (Chukhlib, 2004, pp. 493-499). 
At the same time, according to T. Chukhlib, the fact that in the internal life of the Hetmanate not all processes were destructive and it was impossible to bring a number of phenomena under the category "Ruin". It worked against the term usage. After all, the second half of the XVIIth century, despite the loss of statehood compared to B. Khmelnytskyi era, was the era of final international recognition of the Hetmanate, crystallization of the new Ukrainian elite, elaboration of the idea of the Hetmanate as Russia's successor, approval of a new model of economic relations and social communication (Chukhlib, 2004, pp. 500-501).

In the end, diverse attempts, which were made in order to delineate Ruin chronologically also ran into difficulties. T. Chukhlib denied the boundaries of $1658-1687$ defined by T. TairovaYakovleva as blurred. In the first case, he used the argument of illegality to identify the beginning of open internal conflicts with the "Ruin". The upper limit was unacceptable, because Ivan Mazepa in key features continued the course of I. Samoilovych, and stabilization in the Left Bank Hetmanate was achieved during the Hetmanship of the latter (Chukhlib, 2004, p. 501).

As a result, T. Chukhlib's point of view was reduced to the fact that the period to which the concept was proposed to be used did not have that kind of uniqueness to use the term with such a semantic load as "Ruin".

Moreover, from the point of view of the European context, the Hetmanate "experienced a period of normal (!) State-political formation" in the sense of typological echoes in key strategies of elites, because "almost every newly created world power experienced a natural stage of internal political struggle", which quite often had a foreign policy "color" (Chukhlib, 2004 , p. 492). The only problem was that these elites, entered the "normal" canvas, could not cope with internal and external challenges, which ultimately narrowed the prospects of the Hetmanate, laid in the time of B. Khmelnytskyi.

T. Tairova-Yakovleva did not remain in debt and tried to respond to the accusations of the Ukrainian researcher. By the way, her article was published in the next issue of the collection "Ukraine in Central and Eastern Europe", edited by T. Chukhlib, which testifies to the establishment of a proper culture of scientific discussions. It should be mentioned that the researcher highlighted immediately a key point that, at a basic level, determined both this and other discussions between the Ukrainian and the Russian researchers and which they prefer to chastely as if it does not exist: "History is a political science, and we with our Ukrainian colleagues will always, to one degree or another, look at the same things from different points of view" (Yakovleva, 2005, p. 670). Then T. Tairova-Yakovleva proposed to divide the problem into two issues: the term "Ruin" and the name of the period, rightly noting that in science periods were often outlined by vivid concepts, which did not have a scientific background ("Smuta", "Flood", etc.). Therefore, the term "Ruin" has the right to life. At the same time, the researcher, however, skipped the issue raised by T. Chukhlib of the influence of the poly-functionality of the concept (in contrast to the same "Smuta" or "Flood" on the general image of the day and its echo in historical memory.

Similarly, T. Tairova-Yakovleva preferred not to answer the main argument of the Ukrainian researcher - the echo of the processes with European counterparts. The emphasis was placed on the negative trends of the day, which in the end did little to convince in favor of the concept "Ruin". Consequently, that is why, no one tried to emphasize the position of T. Tairova-Yakovleva. Instead, T. Chukhlib once again duplicated his arguments in the edition of 2018 (Smolii, 2018, pp. 393-399). The paramount historiographical tendency both in Ukraine and abroad stretched towards the unaccented use of the term as a non-scientific marker like the "Flood". We often come across reservations, such as events "prompted 
many historians to call the next decades after the uprising Ruin" (Plokhii, 2016, p. 154). Even O. Sokyrko, who introduced the concept "Ruin" in the title of his book on the Battle of Konotop in 1659 ("The Triumph in the Time of Ruin"), called the concept "terrible" (Sokirko, 2009 , p. 4). V. Brekhunenko, despite the proposal to use the term "The Civil War of 1658 1676 ", to fit the Ukrainian situation more closely into the European context and, following T. Chukhlib, in order to put emphasis on the "normality", continues to use the term "Ruin" instrumentally (Brekhunenko, 2014, pp. 6, 110, 161, 220, 270). The researchers V. Smolii and V. Stepankov decided to distance themselves from the concept. And from the fact that they spread the Ukrainian national revolution to 1648 - 1676, a negative attitude to the use of the concept probably follows (Smolii, Stepankov, 2009, pp. 5-6). In the Polish historiography, the "Ruin" also continues to be used metaphorically without attempting to typologize the phenomenon (Kossarzhetskyi, 2006, p. 565; Kaczmarczyk, 2007, pp. 72, 138; Kroll, 2004, p. 9).

The Conclusions. Modern scientific discourse around the concept "Ruin" reflected the key trends in understanding the history of early modern Ukrainian statehood. At the beginning of the XXIst century for the first time in historiography the problem reached the level of discussion of the grounds for using the concept, while in the previous tradition it was used without being discussed. The focus of the controversy was the discussion between the Ukrainian historian T. Chukhlib and the Russian researcher T. Tairova-Yakovleva, a representative of the modernist wing in modern Russian historiography.

The depth of the discussion was ensured by T. Chukhlib's energetic attempts to derive approaches from the typology on the European background of the essence of the processes that are proposed to be marked as the "Ruin". And it was in this field that the limitations of the positions of T. Tairova-Yakovleva, a consistent supporter of functioning of "Ruin" in the scientific circulation, appeared. The reaction of interested researchers was to reduce the concept to the level of metaphor and transfer the final verdict to future more detailed research and deeper typology. The situation echoed the approaches to the terminological apparatus, focused on the problem of formation of early modern Ukrainian statehood, when neither side was able to achieve dominance, that is why, in the scientific space continue to be in circulation such terms as "The National Liberation War", "The Cossack evolution", "The National revolution", "Bohdan Khmelnytskyi Uprising” as identical.

Acknowledgments. We express sincere gratitude to all members of the editorial board for consultations provided during the preparation of the article for printing.

Financing. The authors did not receive financial support for the research, authorship and publication of this article.

\section{BIBLIOGRAPHY}

Brekhunenko, V. (2014). Skhidna brama Yevropy.Kozatska Ukraina seredyny XVII - XVIII st. [Eastern Gate of Europe. Cossack Ukraine in the Middle of the XVIIth - the XVIIIth Centuries] Kyiv: Tempora, 504 p. [in Ukrainian]

Chukhlib, T. (2004). "Ruina" Hetmanshchyny chy borotba za utverdzhennia Ukrainskoi kozatskoi derzhavy (sproba zapochatkuvaty dyskusiiu shchodo odnoho istorychnoho terminu) [The "Ruin" of the Hetmanate or the Struggle for the Establishment of the Ukrainian Cossack State (An Attempt to Initiate a Discussion of a Historical Term). Ukraina v Tsentralno-Skhidnii Yevropi (vid naidavnishykh chasiv do kintsia XVIII st. - Ukraine in the Central and Eastern Europe (from ancient times to the end of the XVIII century, 4, 474-502. [in Ukrainian]

Drozdowski, M. (2011). Jan III Sobieski wobec Ukrainy [Jan III Sobieski and Ukraine]. In Chynczewska-Hennel, Tereza (ed.) Odsiecz wiedeńska. (pp.75-86). Warszawa: Wilanów. [in Polish] 
Gierowski, J. A. (2004). Rzeczpospolita w dobie złotej wolności (1648 - 1763) [Republic in the Era of Golden Liberties 1648 - 1763]. In Gierowski, J. A. (ed.) Wielka Historia Polski. Kraków: Fogra, 5, 414 p. [in Polish]

Horobets, V. \& Chukhlib, T. (1999). Istoriia ukrainskoi Ruiny ochyma rosiiskoho istoryka [History of the Ukrainian Ruins through the Eyes of the Russian Historian]. Naukovi zapysky NAUKMA - Scientific notes of NAUKMA. Kyiv: Vydavnychyi dim “Kyievo-Mohylianska Akademiia”, 14, 118123. [in Ukrainian]

Horobets, V. (1999). Nemaie proroka u svoii vitchyzni. A v chuzhii? (Istoriia ukrainskoi Ruiny v interpretatsii rosiiskoi doslidnytsi) [There is no Prophet in his Homeland. And in someone else's?(History of the Ukrainian Ruin in the interpretation of the Russian researcher)]. Ukrainskyi humanitarnyi ohliad, 2, 46-65. [in Ukrainian]

Horobets, V. (2001). Platon meni druh. I tse naidorozhche?... [Plato is my friend. And this is the most expensive? ...]. Ukrainskyi humanitarnyi ohliad, 5, 217-221). [in Ukrainian]

Kaczmarczyk, J. (2007). Rzeczpospolita Trojga Narodów. Mit czy rzeczywistość. Ugoda hadziacka - teoria i praktyka [Republic of three nations. Myth or reality. Effective agreement - theory and practice]. Kraków: UJ, 186 p. [in Polish]

Kasianov, H. \& Tolochko, O. (2012). Natsionalni istorii ta suchasna istoriohrafiia. Vyklyky y nebezpeky pry napysanni novoi istorii Ukrainy [National Histories and Modern Historiography. Challenges and Dangers in Writing a New History of Ukraine]. Ukrainskyi istorychnyi zhurnal, 6, 4-24. [in Ukrainian]

Kohut, Z. (1996). Rosiiskyi tsentralizm $i$ ukrainska avtonomiia. Likvidatsiia Hetmanshchyny 1760 - 1830 [The Russian Centralism and Ukrainian Autonomy. Liquidation of the Hetmanate in 1760 - 1830]. Kyiv: Osnovy, 317 p. [in Ukrainian]

Kossarzhetskyi, K. (2006). Dzherela arkhivu Radzyviliv (AHAD) pro stosunky kniazia Bohuslava Radzyvila z kozatskoiu Ukrainoiu v 1655 - 1669 rokakh [The sources of the Radziwills' Archive (AGAD) on the relations of Prince Boguslaw Radziwill with Cossack Ukraine in 1655 - 1669]. Ukraina $v$ Tsentralno-Skhidnii Yevropi (z naidavnishykh chasiv do kintsia XVIII st. - Ukraine in the Central and Eastern Europe (from ancient times to the end of the 18th century), 6, 548-570. [in Ukrainian]

Kroll, P. (2004). Bitwa pod Konotopem (8 lipca 1659) - przyczynek do dziejów wojskowości kozackiej [The Battle of Konotop (July 8, 1659) - materials on the history of military Cossack affairs]. Materiaty do historii wojskowości, Puttusk, 2, 113-132. [in Polish]

Maslak, V. (2014). Rannomoderna ukrainska derzhavnist ochyma suchasnykh polskykh ta rosiiskykh istorykiv [The Early Modern Ukrainian Statehood through the Eyes of Modern Polish and Russian Historians]. Kamianets-Podilskyi, 354 s. [in Ukrainian]

Mytsyk, Yu. A. (1990). Aktualni pytannia doslidzhennia istorii ukrainskoho kozatstva. Ukrainske kozatstvo: suchasnyi stan ta perspektyvy doslidzhennia problemy (Materialy "kruhloho stolu") [Current Issues of Research of the History of the Ukrainian Cossacks. Ukrainian Cossacks: current state and prospects of research of the problem (Materials of the "round table")]. Ukrainskyi istorychnyi zhurnal, 12, 24-26. [in Ukrainian]

Mytsyk, Yu. A., Bazhan, O. H. \& Vlasov, V. S. (2010). Istoriia Ukrainy [History of Ukraine. Tutorial]. Kyiv: Vydavnychyi dim "Kyievo-Mohylianska akademiia", 594 p. [in Ukrainian]

Ohloblyn, O. (1928). Do istorii Ruiny [On the History of the Ruin]. Zapysky istoryko-filolohichnoho viddilu VUAN, XVI, 196-204. [in Ukrainian]

Ohloblyn, O. (2001). Ivan Mazepa ta yoho doba [Ivan Mazepa and his time.]. Druhe dopovnene vydannia. Niu-York; Kyiv; Lviv; Paryzh; Toronto, 2001, 464 p. [in Ukrainian]

Perdenia, J. (2000). Hetman Piotr Doroszenko a Polska [Hetman Petro Doroshenko and Poland]. Kraków, 502 p. [in Polish]

Plokhii, S. (2016). Brama Yevropy. Istoriia Ukrainy vid skifskykh voien do nezalezhnosti [The Gate of Europe. History of Ukraine from the Scythian Wars to Independence]. Kharkiv: Klub simeinoho dozvillia, 496 p. [in Ukrainian]

Serczyk, Wl. (1979). Historia Ukrainy [The History of Ukraine]. Wrocław, 648 p. [in Polish]

Smolii, V. \& Stepankov, V. (1993). Pravoberezhna Ukraina u druhii polovyni XVII - XVIII st: problema derzhavotvorennia [The Right-bank Ukraine in the Second Half of the XVIIth XVIIIth centuries: the problem of state formation]. Kyiv, 72 p. [in Ukrainian] 
Smolii, V. \& Stepankov, V. (2009). Ukrainska natsionalna revoliutsiia XVII st. (1648 - 1676 rr.) [The Ukrainian National Revolution of the XVIIth century (1648 - 1676)]. Kyiv: Vydavnychyi dim "Kyievo-Mohylianska Akademiia", 447 p. [in Ukrainian]

Smolii, V. A. (ed.) (1997). Malyi slovnyk istorii Ukrainy [A Consize Dictionary of the History of Ukraine]. Kyiv: Lybid, 464 p. [in Ukrainian]

Smolii, V. A. (ed.) (2018). Ukrainskyi Hetmanat: narysy istorii natsionalnoho derzhavotvorennia XVII - XVIII st. u 2-kh kn [The Ukrainian Hetmanate: essays on the history of national state formation of the XVII - XVIII centuries in 2 books]. Kyiv: Instytut istorii Ukrainy NANU, Book 1, $610 \mathrm{p}$. [inUkrainian]

Sokyrko, O. (2009). Triumf v chas Ruiny. Konotopska bytva 1659 roku [Triumph during the Ruin. The Battle of Konotop in 1659]. Kyiv: Tempora, 70 p. [in Ukrainian]

Stepankov, V. (2003). 1648 rik: pochatok Ukrainskoi revoliutsii chy "domovoi viiny" v Rechi Pospolytii? [1648 year: the beginning of the Ukrainian revolution or the "house war" in Rich Pospolyta? Smoliy, VA (ed.)]. Ukraina $v$ Tsentralno-Skhidnii Yevropi (vid naidavnishykh chasiv do kintsia XVIII st. - Ukraine in the Central and Eastern Europe (from ancient times to the end of the XVIII century, 3, 369-414. [in Ukrainian]

Stepankov, V. \& Chukhlib, T. (1994). Tetiana Yakovlieva pro pochatok Ruiny [Tetyana Yakovleva about the Beginning of the Ruin]. In Dashkevych, Ya. (ed.) Ukraina v mynulomu [Dashkevych, Ya. (Ed.) Ukraine in the Past]. (Vol. VI, pp. 184- 192). Lviv. [in Ukrainian]

Subtelny, O. (1989). Ukraine. A History. Toronto, Buffalo, London: University of Toronto Press, 666 p. [in English]

Wójcik, Z. (1989). Wojny kozackie w dawnej Polsce [Cossack Wars in Ancient Poland]. Warszawa, 80 p. [in Polish]

Yakovenko, N. (2005). Narys istorii serednovichnoi ta rannomodernoi Ukrainy [Essay on the History of Medieval and Early Modern Ukraine]. Vydannia druhe, pereroblene ta rozshyrene. Kyiv: Krytyka, 584 p. [in Ukrainian]

Yakovleva, T. (1998). Hetmanshchyna $v$ druhii polovyni 50-kh rr. XVII stolittia Prychyny $i$ pochatok Ruiny [Hetmanate in the Second Half of the 50s of the XVIIth century]. Kyiv: Osnovy, 447 p. [in Ukrainian]

Yakovleva, T. (2003). Ruina Hetmanshchyny. Vid Pereiaslavskoi rady-2 do Andrusivskoi uhody (1659-1667 rr.) [Ruin of the Hetmanate.From the Pereyaslav Council-2 to the Andrusivska Agreement (1659-1667)]. Kyiv: Osnovy, 644 p. [in Ukrainian]

Yakovleva, T. (2005). Ukrayna v XVII veke: Ruyna, revoliutsyia [Ukraine in the XVIIth Century: Ruin, Revolution]. Ukraina $v$ Tsentralno-Skhidnii Yevropi (vid naidavnishykh chasiv do kintsia XVIII st. - Ukraine in the Central and Eastern Europe (from ancient times to the end of the XVIII century, 5, 667-672. [in Russian]

The article was received November 27, 2020. Article recommended for publishing 31/08/2021. 